\title{
Ethyl acetate extract of Kaempferia parviflora inhibits Helicobacter pylori- associated mammalian cell inflammation by regulating proinflammatory cytokine expression and leukocyte chemotaxis
}

\author{
Variya Nemidkanam', Yuko Kato², Tetsuo Kubota ${ }^{2}$ and Nuntaree Chaichanawongsaroj ${ }^{3 *}$
}

\begin{abstract}
Background: Kaempferia parviflora (KP) has been used in traditional Thai medicine to cure gastrointestinal disorders since ancient times. Helicobacter pylori is an initiating factor in gastric pathogenesis via activation of massive inflammation, the cumulative effect of which leads to gastric disease progression, including gastric carcinogenesis. Accordingly, the effect of a crude ethyl acetate extract of KP (CEAE-KP) on proinflammatory cytokine production and cell chemotaxis was the focus of this study.

Methods: The cytotoxicity of CEAE-KP $(8-128 \mu \mathrm{g} / \mathrm{ml})$ on AGS (gastric adenocarcinoma) cells was determined at 6, 12 and $24 \mathrm{~h}$ using an MTT assay. The effect of CEAE-KP on H. pylori-induced interleukin (IL)-8 production by AGS cells was evaluated by ELISA and RT-PCR. The effect of CEAE-KP on monocyte and neutrophil chemotaxis to $H$. pylori soluble protein (SHP) and IL-8, respectively, was determined using a Boyden chamber assay with THP-1 or HL60 cells.

Results: CEAE-KP reduced AGS cell viability in a concentration- and time-dependent manner, but at $8-16 \mu \mathrm{g} / \mathrm{ml}$, it was not cytotoxic after 6-24 h of exposure. Coculture of AGS cells with CEAE-KP at a noncytotoxic concentration of $16 \mu \mathrm{g} / \mathrm{ml}$ and $\mathrm{H}$. pylori reduced IL-8 secretion by $\sim 60 \%$ at $12 \mathrm{~h}$, which was consistent with the decreased level of mRNA expression, and inhibited neutrophil chemotaxis to IL-8. sHP (100 ng/ml) induced marked monocyte chemoattraction, and this was decreased by 60\% by CEAE-KP.

Conclusion: CEAE-KP might serve as a potent alternative medicine to ameliorate the inflammation mediated by $\mathrm{H}$. pylori infection.
\end{abstract}

Keywords: Kaempferia parviflora, Helicobacter pylori, Inflammation, Interleukin-8, Chemotaxis

* Correspondence: nuntaree@gmail.com

${ }^{3}$ Research Unit of Innovative Diagnosis of Antimicrobial Resistance, Department of Transfusion Medicine and Clinical Microbiology, Faculty of Allied Health Sciences, Chulalongkorn University, Pathumwan, Bangkok, Thailand

Full list of author information is available at the end of the article

\section{Background}

Helicobacter pylori is of considerable concern as a gastric pathogen and is one of the factors associated with peptic ulcers and various types of gastric cancer, such as gastric adenocarcinoma and gastric mucosa-associated lymphoid tissue lymphoma [1]. Approximately half of the population worldwide are infected with $H$. pylori and

(c) The Author(s). 2020 Open Access This article is licensed under a Creative Commons Attribution 4.0 International License, which permits use, sharing, adaptation, distribution and reproduction in any medium or format, as long as you give appropriate credit to the original author(s) and the source, provide a link to the Creative Commons licence, and indicate if changes were made. The images or other third party material in this article are included in the article's Creative Commons licence, unless indicated otherwise in a credit line to the material. If material is not included in the article's Creative Commons licence and your intended use is not permitted by statutory regulation or exceeds the permitted use, you will need to obtain permission directly from the copyright holder. To view a copy of this licence, visit http://creativecommons.org/licenses/by/4.0/ The Creative Commons Public Domain Dedication waiver (http://creativecommons.org/publicdomain/zero/1.0/) applies to the data made available in this article, unless otherwise stated in a credit line to the data. 
thus have an increased gastric cancer risk. The common H. pylori transmission route is gastro-oral through consuming contaminated food and drink. Eating traditional raw foods, such as pickled fish and papaya salad, has a high predictive value for $H$. pylori infection [2]. Milk from livestock and bottled mineral water have also been found to have $H$. pylori contamination and could play a role in spreading the infection $[3,4]$. Because of the effortless route of $H$. pylori transmission, a high infection prevalence is found, especially in countries that have unhygienic food preparation and consumption habits $[5,6]$. From 2000 to 2015, clarithromycin and levofloxacin resistance increased in the Asia-Pacific region [7], reducing the efficacy of $H$. pylori eradication regimens. Unfortunately, the prevention of $H$. pylori infection by establishing a vaccine is still unsuccessful due to $H$. pylori antigen adaptation and difficulties in vaccine delivery [8]. As a result, various medicinal plants have been explored for their antimicrobial and pharmacological activities to combat $H$. pylori infection with minimal side effects.

H. pylori alters host gastric cell signaling pathways via secreted virulence factors, including upregulating inflammation. The bacteria express a variety of soluble protein antigens that initiate an inflammatory signal, such as cytotoxin-associated gene A (Cag A), vacuolated toxin A (Vac A), neutrophil-activating protein and heat shock protein [9]. Soluble H. pylori proteins (sHPs) stimulate eosinophil, monocyte and neutrophil functions, leading to the production of related inflammatory cytokines and reactive oxygen species [10-12]. Most of the antigens activate NF- $\mathrm{KB}$ functions through the MAPK/ERK and PI3K/Akt signaling pathways $[13,14]$ and result in the extended production of proinflammatory molecules, in-

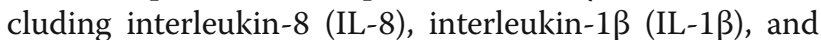
monocyte chemoattractant protein-1 (MCP-1) [15]. These molecules function as chemokines to recruit neutrophils and monocytes into the infection area. Consequently, the functions of inflammatory cells enhance the severity of gastric disease [16-18]. Incurable H. pylori infection can lead to chronic gastritis, which is an initial stage of gastric carcinogenesis. Recently, evaluation of the inflammation-related carcinogenesis mechanism revealed that inflammatory byproducts induce DNA damage that then leads to mutation and genomic instability of the cell [19].

Kaempferia parviflora Wall. Ex Baker (KP), or KraChai-Dum, is a Thai medicinal plant within the ginger (Zingiberaceae) family. Its rhizome has traditionally been used to relieve gastric symptoms. Methoxyflavone was identified as an active component in the KP rhizome with a variety of biological properties, while KP activities include the support of sexual performance and antioxidant, antitumor growth and metastasis, bactericidal and anti-inflammatory effects [20-24]. The ethanol extract of KP inhibits Cronobacter spp., enterohemorrhagic Escherichia coli and H. pylori growth, which are offensive gastro-enteric pathogens [25]. In a previous study, the crude ethyl acetate extract of KP (CEAE-KP) was shown to reduce $H$. pylori pathogenic function by inhibiting their internalization process in human laryngeal carcinoma cells [26]. The ethanol extract of KP suppressed proinflammatory cytokine gene expression in antigen-stimulated rat basophilic leukemia cells and reduced nitric oxide production in LPS-activated mouse macrophage cells [27]. Moreover, KP has a gastroprotective effect by preventing gastric ulcer formation and maintaining the gastric wall mucus content in a rat model [28].

Because $H$. pylori is a potent stimulant of inflammation-induced cancer and KP might be used as a novel alternative medicine to improve the efficacy of $H$. pylori treatment, we assessed the in vitro regulatory role of CEAE-KP on H. pylori-induced inflammation in a human gastric cell line and chemotaxis of relevant inflammatory cells.

\section{Methods}

\section{Chemicals and reagents}

Dimethyl sulfoxide (DMSO) was purchased from SigmaAldrich (St. Louis, MO, USA). Thiazolyl blue tetrazolium bromide (MTT) was obtained from Bio Basic (Markham, ON, Canada). Fetal bovine serum (FBS), RPMI, antibiotics and antimycotic agents were procured from GE Healthcare (Chicago, IL, USA). The human IL-8 ELISA kit was purchased from Abcam (Cambridge, UK). The GENEzol reagent kit was obtained from Geneaid Biotech (New Taipei City, Taiwan). RevertAid M-MuLV reverse transcriptase was purchased from Thermo Fisher Scientific (Waltham, MA, USA), and Taq DNA Polymerase was obtained from New England Biolabs (Ipswich, MA, USA).

\section{Plant materials and extraction}

KP was purchased from a traditional Thai drug store in Bangkok, Thailand. The plant material was identified by Dr. Eakarin Saifah of the Department of Pharmaceutical Botany, Faculty of Pharmaceutical Sciences, Chulalongkorn University, Bangkok, Thailand, and a specimen voucher (number ES280306) was deposited at the herbarium of this university. The extraction was performed by the maceration method as described previously [26]. Briefly, roughly ground, air-dried KP was extracted in $200 \mathrm{ml}$ ethyl acetate solvent for $48 \mathrm{~h}$ at room temperature. The solvent phase was collected and evaporated at $40{ }^{\circ} \mathrm{C}$ until dry to yield the CEAE-KP and weighed. This was then dissolved in DMSO to a concentration of $0.1 \mathrm{~g} / \mathrm{ml}$ and sterilized by $0.2 \mu \mathrm{m}$ pore size 
filtration to form the stock solution, which was stored at $-20^{\circ} \mathrm{C}$ in the dark until use.

\section{Cell lines (AGS, THP-1 and HL-60) and culture}

The AGS cell line (kindly provided by Dr. Panan Ratthawongjirakul of the Faculty of Allied Health Sciences, Chulalongkorn University, Thailand) was cultured in complete medium (CM; RPMI 1640 containing 10\% (v/ v) fetal bovine serum) supplemented with $1 \%(\mathrm{v} / \mathrm{v})$ antibiotics and antimycotics at $37{ }^{\circ} \mathrm{C}$ in $5 \% \mathrm{CO}_{2}$ and $80 \%$ humidity. The cells were harvested at $80-90 \%$ cell confluence by $0.25 \%$ EDTA-trypsin. The THP-1 cell line was provided by Dr. Tetsuo Kubota (Tokyo Medical and Dental University, Tokyo, Japan). Human promyelocytic leukemia HL-60 cells were obtained from the RIKEN BioResource Center (Tsukuba, Japan). Cells were cultured in CM in the same manner as AGS cells.

\section{Cell viability (cytotoxicity assay) assessment using thiazolyl blue tetrazolium bromide (MTT)}

AGS cells $\left(1 \times 10^{4}\right.$ cells/well $)$ were seeded in 96-well plates and incubated in CM without antibiotics for $24 \mathrm{~h}$. The cells were then washed, and various concentrations of CEAE-KP $(8-128 \mu \mathrm{g} / \mathrm{ml})$ were added to each test well and incubated for 6,12 and $24 \mathrm{~h}$ before $5 \mathrm{mg} / \mathrm{ml} \mathrm{MTT}$ was added and incubated for an additional $4 \mathrm{~h}$ in the dark. The media were then removed, and the cells were permeabilized in $100 \mu \mathrm{l} 10 \%(\mathrm{w} / \mathrm{v})$ SDS in $0.01 \mathrm{~N} \mathrm{HCl}$ to solubilize the formazan crystals. The absorbance was read at $570 \mathrm{~nm}\left(\mathrm{~A}_{570}\right)$ using a Synergy 2 microplate reader (BioTek, Winooski, VT, USA), and the \% cell survival was compared with the negative control as follows:

Cell viability $(\%)=\left[\left(\mathrm{A}_{570(\mathrm{KP}}\right.\right.$ extract treated sample $) /$

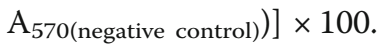

\section{Bacterial stain and culture conditions}

H. pylori ATCC 43504 was cultured on 7\% (v/v) sheep blood-enriched brain heart infusion agar and incubated at $37^{\circ} \mathrm{C}$ for $3 \mathrm{~d}$ in an anaerobic jar with an Anaero Pack-MicroAero Gas Pack (Mitsubishi gas chemical, Japan) to create microaerobic conditions $\left(6-12 \% \mathrm{O}_{2}\right.$ and $\left.5-8 \% \mathrm{CO}_{2}\right)$.

\section{Soluble $H$. pylori protein (sHP) extraction}

A 3-d-old culture of $H$. pylori was harvested, washed and resuspended in phosphate buffered saline (PBS) at $1 \times 10^{8}$ colony forming units $/ \mathrm{ml}$ and then lysed by Vibra Cell sonicator (Sonics \& Materials, Newtown, CT, USA) with 30 times, 10-s pulses on ice at an amplitude of $40 \mu \mathrm{m}$. Following sonication, the residual intact cells and cell debris were removed by centrifugation at $15,000 \mathrm{~g}$ for $30 \mathrm{~min}$, and the supernatant was filtered through a $0.2 \mu \mathrm{m}$ filter to yield the sHP, which was stored at $80^{\circ} \mathrm{C}$ until use. The protein concentration of sHP was determined by the Bradford method using bovine serum albumin as the standard.

\section{Measurement of IL-8}

AGS cells $\left(5 \times 10^{4}\right.$ cells/well) in CM (without antibiotic) were seeded in 24-well plates and incubated for $24 \mathrm{~h}$. Experimental groups were inoculated with $H$. pylori (multiplicity of infection $=1: 100$ ) and 16 or $32 \mu \mathrm{g} / \mathrm{ml} \mathrm{CEAE-}$ KP and then cultured for 6,12 or $24 \mathrm{~h}$, as in the MTT assay. The plates were then centrifuged to pellet the cells and debris, and the supernatant was collected. The IL-8 concentration was then determined using a human IL-8 ELISA kit according to the manufacturer's instructions, reading the absorbance at $450 \mathrm{~nm}$ with a microplate reader and calculating the IL- 8 concentration from the IL-8 standard curve.

\section{RNA preparation and reverse transcription polymerase chain reaction (RT-PCR)}

AGS cells $\left(3 \times 10^{5}\right.$ cells/well) in CM (without antibiotics) were seeded in 6-well plates and incubated for 24 h. Experimental groups were treated with $H$. pylori at a multiplicity of infection of $1: 100$ or $\mathrm{sHP}$ at $100 \mathrm{ng} / \mathrm{ml}$ and were cocultured with 16 or $32 \mu \mathrm{g} / \mathrm{ml} \mathrm{CEAE-KP} \mathrm{for}$ $12 \mathrm{~h}$. Total RNA was then extracted using a GENEzol reagent kit and converted into cDNA using a reverse transcription system with Oligo $(\mathrm{dT})_{18}$ and RevertAid MMuLV reverse transcriptase. The cDNA was separately amplified with each primer pair shown in Table 1. Each $25 \mu \mathrm{l}$ reaction contained $1 \times$ PCR buffer, $0.2 \mathrm{mM}$ dNTPs, $0.2 \mu \mathrm{M}$ each primer, and $0.25 \mathrm{U}$ Taq DNA polymerase. Amplification consisted of $94^{\circ} \mathrm{C}$ for $3 \mathrm{~min}, 35$ cycles of $94{ }^{\circ} \mathrm{C}$ for $30 \mathrm{~s}, 57^{\circ} \mathrm{C}$ for $30 \mathrm{~s}$, and $72{ }^{\circ} \mathrm{C}$ for $30 \mathrm{~s}$, and a final extension at $72^{\circ} \mathrm{C}$ for $5 \mathrm{~min}$. The PCR products were then separated on a $1.5 \%$ agarose gel and visualized under a ChemiDoc XRS gel photo documentation system (Bio-rad, Hercules, CA, USA). The intensity of each band was determined by Image J software.

\section{Monocyte migration assay}

Transwells containing $5-\mu \mathrm{m}$ pore size polycarbonate filters (Corning, NY, USA) were precoated with human fibronectin by incubation at $37^{\circ} \mathrm{C}$ for $1 \mathrm{~h}$ and washed twice in PBS. The transwells were inserted into the lower chambers, which contained starvation medium (RPMI 1640 containing 0.1\% (v/v) fetal bovine serum) alone for the negative control or medium supplemented with either $10 \mathrm{ng} / \mathrm{ml}$ platelet-derived growth factor-BB (PDGF-BB) for the positive control or $10-10,000 \mathrm{ng} / \mathrm{ml}$ sHP for the infection groups. THP-1 cells were cultured in starvation medium for $2 \mathrm{~d}$ before testing. Cells were centrifuged at $200 \mathrm{~g}$ for $5 \mathrm{~min}$, resuspended in $1 \mathrm{ml}$ starvation medium and passed through a $40 \mu \mathrm{m}$ cell strainer (BD Falcon, Bedford, MA, USA). THP-1 cells $\left(10^{5}\right.$ cells) 
Table 1 Nucleotide sequences used for RT-PCR detection of cytokine mRNA expression

\begin{tabular}{lll}
\hline Gene & Primers & Product size \\
\hline IL-8 & Forward primer 5'-TCC AAA CCT TTC CAC CCC AA-3' & 153 bp \\
& Reverse primer 5'-ACT TCT CCA CAA CCC TCT GC-3' & 172 bp \\
GAPDH & Forward primer 5'-CTG ACT TCA ACA GCG ACA CC-3' & Reverse primer 5'-GTG GTC CAG GGG TCT TAC TC-3' \\
\hline
\end{tabular}

and CEAE-KP $(0,16$ or $32 \mu \mathrm{g} / \mathrm{ml})$ were added to the upper chambers, incubated at $37^{\circ} \mathrm{C}$ for $1.5 \mathrm{~h}$ and washed twice with PBS. Next, $10 \%(\mathrm{w} / \mathrm{v})$ formalin was added and incubated at room temperature for $10 \mathrm{~min}$ to fix the cells. Cells were stained with Cytoquick (Muto Pure Chemical, Japan), gently washed with water to remove the excess stain, and dried overnight. Cells that did not migrate were wiped away with a damp cotton swab. The migrated cells were viewed in 10 fields of view under a light microscope with a $20 \times$ objective lens, and the cells were counted using ImageJ software.

\section{Neutrophil migration assay}

Each 5- $\mu \mathrm{m}$ Transwell was precoated with human fibronectin and inserted into the lower chamber, which contained starvation medium alone for the negative control or medium supplemented with $10 \mathrm{ng} / \mathrm{ml}$ IL-8 for the positive control. HL-60 cells were differentiated into neutrophils by induction with $1.25 \%(\mathrm{v} / \mathrm{v})$ DMSO for $6 \mathrm{~d}$, and then DMSO-differentiated HL-60 cells $\left(10^{5}\right)$ and CEAE$\mathrm{KP}(0,16$ or $32 \mu \mathrm{g} / \mathrm{ml})$ were added into the upper chambers and incubated at $37^{\circ} \mathrm{C}$ for $30 \mathrm{~min}$. The cells on the membrane were then washed, fixed, stained and counted as described in the monocyte migration method.

\section{Statistical analysis}

The data are presented as the mean \pm one standard deviation (SD). Statistical analysis was performed with GraphPad Prism 6 (GraphPad Software, San Diego, CA, USA). One-way ANOVA followed by Bonferroni post-tests was used to compare the control and test groups. The effects of the treatment over time were analyzed by two-way ANOVA followed by Bonferroni post-tests. Values of $p \leq$ 0.05 were considered statistically significant.

\section{Results}

\section{Cytotoxicity of CEAE-KP in the AGS cell line}

To evaluate the toxicity of CEAE-KP and select an acceptable (non-toxic) concentration and incubation time, the MTT assay was performed. According to our previous study, the MIC of CEAE-KP was $32 \mu \mathrm{g} / \mathrm{ml}$ [29], and concentrations of CEAE-KP ranging from 8 to $128 \mu \mathrm{g} /$ $\mathrm{ml}$ were examined for cytotoxicity against AGS cells. AGS cell viability was reduced by CEAE-KP in a concentration- and time-dependent manner (Table 2); CEAE$\mathrm{KP}$ at concentrations of 64 and $128 \mu \mathrm{g} / \mathrm{ml}$ significantly reduced AGS cell viability to $69.3 \pm 7.1 \%$ and $36.1 \pm 3.7 \%$ at $6 \mathrm{~h}, 56.7 \pm 9.8 \%$ and $10.8 \pm 5.4 \%$ at $12 \mathrm{~h}$, and $16.6 \pm$ $4.4 \%$ and $1.2 \pm 0.6 \%$ at $24 \mathrm{~h}$, respectively. In addition, $\mathrm{CEAE}-\mathrm{KP}$ at $32 \mu \mathrm{g} / \mathrm{ml}$ was cytotoxic at the longest incubation time $(24 \mathrm{~h})$, reducing cell viability to $72.8 \pm 6.6 \%$. However, 8 and $16 \mu \mathrm{g} / \mathrm{ml} \mathrm{CEAE-KP} \mathrm{was} \mathrm{not} \mathrm{toxic} \mathrm{to} \mathrm{the}$ AGS cell line at any assayed time point. In a previous study, the ethanol extract of KP decreased HL-60 cell viability in a dose- and time-dependent manner, and no cytotoxic effect was noted at concentrations of $0-20 \mu \mathrm{g} /$ $\mathrm{ml}$ for $24 \mathrm{~h} \mathrm{[30].} \mathrm{Thus,} \mathrm{subsequent} \mathrm{experiments} \mathrm{used}$ CEAE-KP at 8 or $16 \mu \mathrm{g} / \mathrm{ml}$ with an incubation time that was limited to $24 \mathrm{~h}$.

Inhibition by CEAE-KP of $H$. pylori-induced IL-8 production and IL-8 mRNA expression

IL-8 is one of the most responsive proinflammatory cytokines in $H$. pylori infection. AGS cells produced IL-8 after in vitro infection with $H$. pylori in a timedependent manner (Table 3), with the highest IL-8 level detected at $24 \mathrm{~h}(421.3 \pm 57.3 \mathrm{pg} / \mathrm{ml})$. A low CEAE-KP concentration $(8 \mu \mathrm{g} / \mathrm{ml})$ did not significantly decrease the IL- 8 level at any assayed incubation time, but $16 \mu \mathrm{g} /$ $\mathrm{ml}$ CEAE-KP significantly reduced the IL- 8 level by 2.3 fold at $6 \mathrm{~h}$ and by 2.07 -fold at $12 \mathrm{~h}$. However, the inhibitory effect of CEAE-KP on IL-8 secretion was limited to up to $12 \mathrm{~h}$, with no significant IL-8 reduction after incubation for $24 \mathrm{~h}$. Both $H$. pylori and sHP dramatically induced IL-8 mRNA expression, and the increased IL-8 was significantly downregulated by CEAE-KP at $16 \mu \mathrm{g} /$ $\mathrm{ml}$ (Fig. 1a and b).

Table 2 Cytotoxicity of CEAE-KP on AGS cells by MTT assay

\begin{tabular}{llll}
\hline Treatment & \multicolumn{3}{l}{ Cell viability (\%) } \\
\cline { 2 - 4 } & \multicolumn{3}{l}{ Time } \\
\cline { 2 - 4 } & $6 \mathrm{~h}$ & $12 \mathrm{~h}$ & $24 \mathrm{~h}$ \\
\hline Media & $100.00 \pm 3.47$ & $98.29 \pm 3.15$ & $98.67 \pm 2.44$ \\
DMSO & $105.00 \pm 10.80$ & $91.56 \pm 7.71$ & $92.98 \pm 6.37$ \\
CEAE-KP $8 \mu \mathrm{g} / \mathrm{ml}$ & $96.69 \pm 15.36$ & $91.25 \pm 5.51$ & $91.16 \pm 9.64$ \\
CEAE-KP $16 \mu \mathrm{g} / \mathrm{ml}$ & $88.08 \pm 12.90$ & $87.65 \pm 4.36$ & $92.44 \pm 4.19$ \\
CEAE-KP $32 \mu \mathrm{g} / \mathrm{ml}$ & $90.80 \pm 13.78$ & $90.36 \pm 5.09$ & $72.76 \pm 6.62^{* * *}$ \\
CEAE-KP $64 \mu \mathrm{g} / \mathrm{ml}$ & $69.31 \pm 7.05^{* * *}$ & $56.74 \pm 9.78^{* * *}$ & $16.57 \pm 4.43^{* * *}$ \\
CEAE-KP $128 \mu \mathrm{g} / \mathrm{ml}$ & $36.10 \pm 3.68 \%^{* * * *}$ & $10.79 \pm 5.40^{* * *}$ & $1.22 \pm 0.58^{* * *}$
\end{tabular}

The results are presented as the mean \pm SD of three independent experiments. Statistical analysis was performed using two-way ANOVA with Bonferroni post hoc tests. The symbol $\left({ }^{* *}\right)$ indicates a $p$-value $\leq 0.001$ compared to the media control 
Table 3 Effect of CEAE-KP on IL-8 secretion by AGS cells infected with $H$. pylori, as measured by ELISA

\begin{tabular}{|c|c|c|c|}
\hline \multirow[t]{3}{*}{ Treatment } & \multicolumn{3}{|l|}{ IL-8 (pg/ml) } \\
\hline & \multicolumn{3}{|l|}{ Time } \\
\hline & $6 \mathrm{~h}$ & $12 \mathrm{~h}$ & $24 \mathrm{~h}$ \\
\hline Media & $0.064 \pm 0.04$ & $0.00 \pm 0.01$ & $5.17 \pm 6.36$ \\
\hline H. pylori & $133.10 \pm 59.75$ & $149.30 \pm 18.39$ & $421.30 \pm 57.30$ \\
\hline H. pylori + DMSO & $123.20 \pm 18.66$ & $147.60 \pm 24.24$ & $429.80 \pm 31.03$ \\
\hline CEAE-KP $8 \mu \mathrm{g} / \mathrm{ml}$ & $138.10 \pm 40.57$ & $161.50 \pm 19.22$ & $499.30 \pm 22.80$ \\
\hline CEAE-KP $16 \mu \mathrm{g} / \mathrm{ml}$ & $57.68 \pm 18.92^{* *}$ & $72.15 \pm 18.64^{* *}$ & $410.20 \pm 30.46$ \\
\hline
\end{tabular}

The results are presented as the mean $\pm S D$ of three independent experiments. Statistical analysis was performed using two-way ANOVA with Bonferroni post hoc tests. The symbol $\left({ }^{* *}\right)$ indicates a $p$-value $\leq 0.01$ compared to the $H$. pylori-infected control
Induction of monocyte chemotaxis by sHP

To investigate the optimal concentration of sHP to activate chemotaxis in THP-1 cells, sHP was added to the lower chamber at concentrations of $0.1-10 \mu \mathrm{g} / \mathrm{ml}$. At 100 $\mathrm{ng} / \mathrm{ml}$, sHP induced chemotaxis in $30 \pm 6$ cells $/ 10$ fields of view, which was similar to that of PDGF-BB ( $28 \pm 8$ cells/ 10 fields of view). Concentrations of sHP greater than $1 \mu \mathrm{g} / \mathrm{ml}$ rapidly attracted THP-1 cells into the lower chamber, leaving no cells on the transmembrane (Fig. 2). These results demonstrated that some intracellular $H$. pylori proteins serve as chemoattractants for monocytes, while sHP at a concentration of $100 \mathrm{ng} / \mathrm{ml}$ was optimal under this assay condition for further experiments.

\section{Inhibition by CEAE-KP of monocyte chemotaxis induced} by sHP

To study the effect of CEAE-KP on the chemotaxis of THP-1 cells, CEAE-KP and THP-1 cells were cocultured in the upper chamber. The number of chemotactic cells

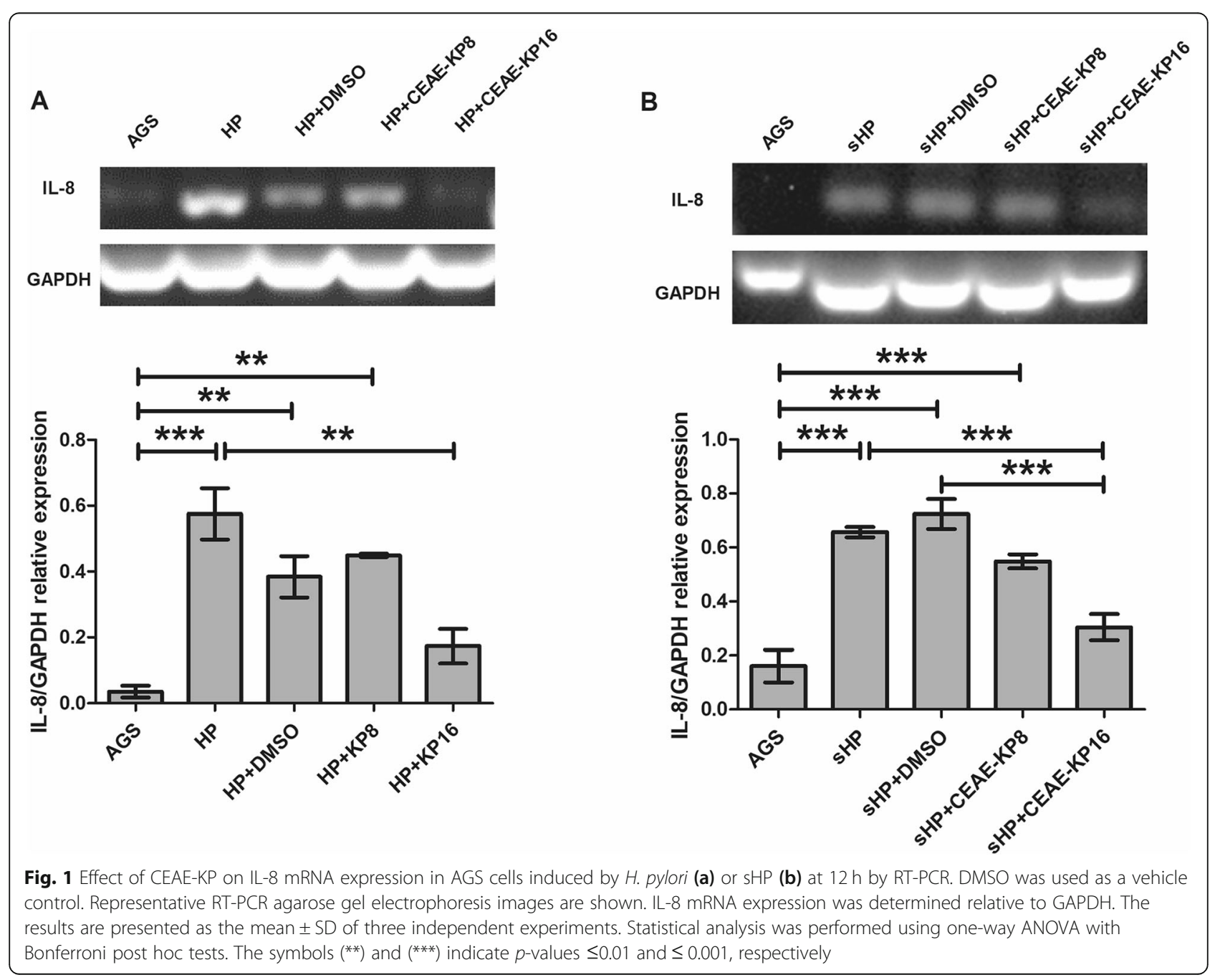



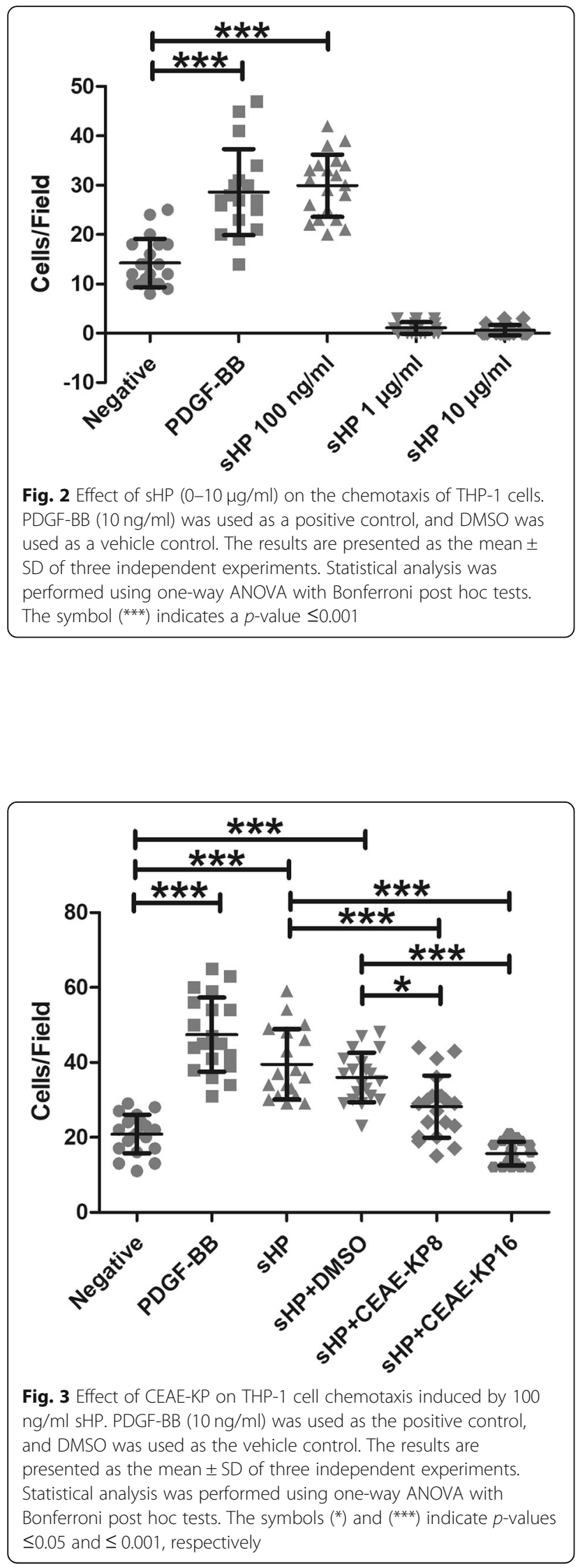

was significantly reduced (1.4-fold) by CEAE-KP at $8 \mu \mathrm{g} /$ $\mathrm{ml}$ and further reduced by 2.5 -fold at $16 \mu \mathrm{g} / \mathrm{ml}$ (Fig. 3).

\section{Inhibition by CEAE-KP of IL-8-induced neutrophil chemotaxis}

Neutrophil participation in gastric inflammation is related to the clearance of $H$. pylori. Neutrophil migration is highly responsive to IL-8; therefore, IL- 8 secreted by gastric epithelial cells is likely to be an important mediator that induces neutrophil migration to the sites of infection. To study the effect of CEAE-KP on neutrophil chemotaxis to IL-8, CEAE-KP and differentiated HL-60 cells were cocultured in the upper chamber. The number of chemotactic cells was significantly reduced (1.4fold) by CEAE-KP at $8 \mu \mathrm{g} / \mathrm{ml}$ and further reduced by 2.5 -fold at $16 \mu \mathrm{g} / \mathrm{ml}$ (Fig. 4).

\section{Discussion}

Most $H$. pylori-infected people are asymptomatic, with only slight gastric inflammation. The asymptomatic nature of this disease results in delayed treatment and can subsequently lead to enhanced inflammation that can affect the severity and progression of gastric disease, starting with gastritis and progressing through atrophy, metaplasia, dysplasia and gastric cancer [31]. Severe stages of gastritis (gastritis stages III and IV) are

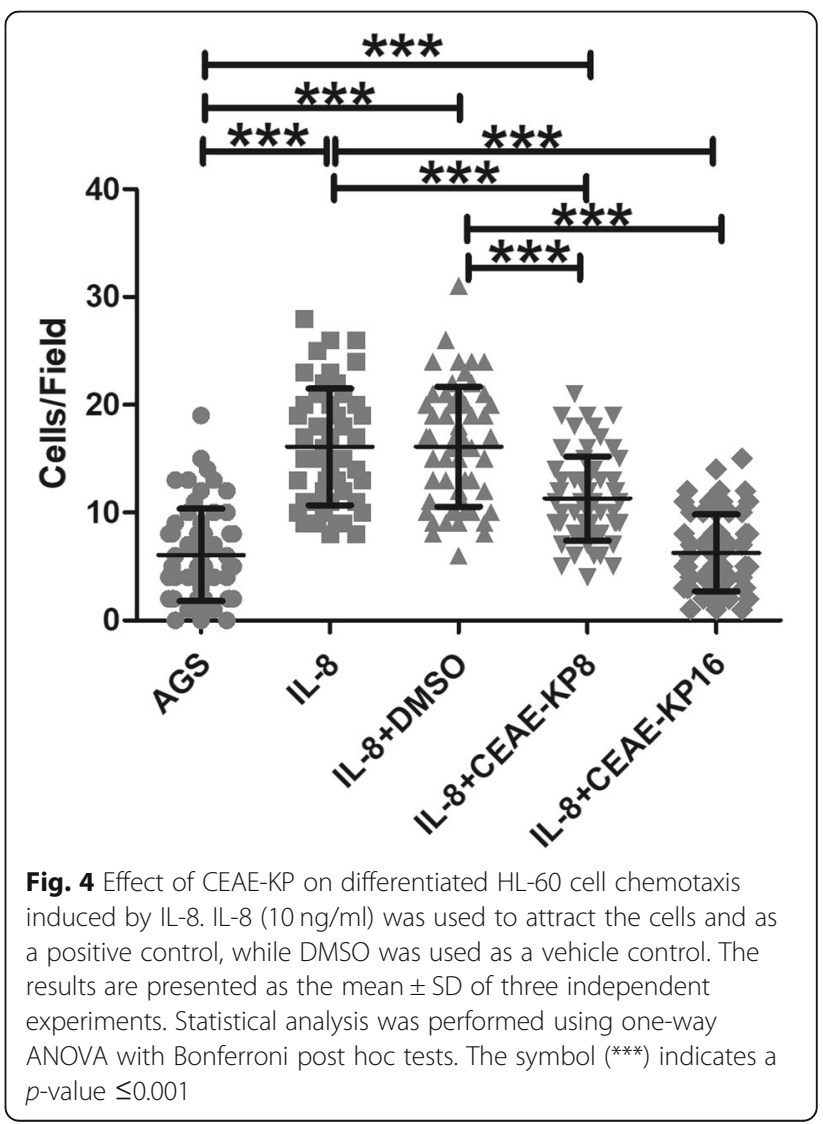


associated with neoplastic prevalence and $H$. pylori infection status [32]. Unfortunately, resistance to clarithromycin, amoxicillin and metronidazole is increasing in $H$. pylori, which reduces the efficacy of triple therapy eradication [33]. Consequently, the Toronto consensus recommended a bismuth quadruple regime as a first-line therapy to improve the worldwide $H$. pylori eradication rate [34]. However, bismuth is a heavy metal that is toxic to mammalian cells [35]. For example, human embryonic kidney cells exposed to bismuth for $48 \mathrm{~h}$ showed a decreased survival rate, and autophagy was detected [36]. Hence, medicinal plants that exhibit antibacterial, anti-inflammatory, antiulcer, and antiapoptotic effects are useful alternative approaches to eradicate $H$. pylori infection and gastric cancer treatment. Several active compounds in herbal plants have been demonstrated to have pharmacological and anti-H. pylori activities, such as curcumin, quercetin, allicin, geraniol, dimethoxyflavone, crocin and safranal [37-40]. Anti-inflammatory action focusing on reducing IL-8 has been demonstrated in many natural products, including Ixeris chinensis [41], Sanguinaria canadensis [42], Lotus tetragonolobus and Maackia amurensis [43].

$K$. parviflora, a plant in the ginger (Zingiberaceae) family, flourishes in the Asia-Pacific region and has been used as a traditional medicine by some ethnic groups in Thailand to treat digestive tract disorders for over a century [44]. In a previous study, CEAE-KP was found to be the most effective extract in terms of active ingredients that disrupt $H$. pylori internalization and growth $(\mathrm{MIC}=$ $32 \mu \mathrm{g} / \mathrm{ml})[26,29]$. However, due to the potential safety concern of KP extracts, the in vitro cytotoxic effect of CEAE-KP on AGS cells was evaluated in this study. CEAE-KP showed time- and concentration-dependent cytotoxicity at concentrations of $32 \mu \mathrm{g} / \mathrm{ml}$ and above but not at low concentrations $(8-16 \mu \mathrm{g} / \mathrm{ml})$ for up to $24 \mathrm{~h}$ (the longest time point assayed), with over $90 \%$ cell survival relative to the control.

According to a genome-wide expression microarray, IL-8 was the single most upregulated gene in AGS cells after stimulation with $H$. pylori [45]. Thus, IL-8 was used as a marker of gastric cell inflammation from $H$. pylori infection. The maximum noncytotoxic concentration of CEAE-KP $(16 \mu \mathrm{g} / \mathrm{ml})$ reduced IL-8 secretion from infected AGS cells by approximately $60 \%$ at 6 and $12 \mathrm{~h}$, but this then declined, and no inhibition of IL- 8 secretion was observed at $24 \mathrm{~h}$. Similarly, the mRNA level of IL-8 was decreased by CEAE-KP treatment. These results indicated that CEAE-KP has an inhibitory effect that downregulates proinflammatory cytokines induced by $H$. pylori infection. The highest DMSO concentration $(0.016 \%(\mathrm{v} / \mathrm{v}))$ in CEAE-KP was also tested in this study as a vehicle control and showed no significant effect on IL-8 secretion in AGS cells. Hollebeeck et al. found that
DMSO ranging from $0.05-1 \%$ did not have any significant effect on IL-8 secretion in intestinal Caco-2 cells. However, DMSO at 0.1 and $0.5 \%$ downregulated IL-1, IL-6 and COX-2 mRNA expression [46].

Neutrophils are IL-8-sensitive inflammatory cells that have high expression of IL- 8 receptors (CXCR1 and CXCR2) on their membrane $[47,48]$. Ligand activation of the receptor induces signaling molecules in the neutrophil chemotaxis cascade, such as phosphoinositide 3kinase- $\gamma$, phospholipase $\mathrm{C}$ and extracellular signalregulated kinase. Consequently, neutrophils undergo chemotaxis towards the infection site, which is an IL-8 source [49]. The extensive IL-8 production induced by H. pylori infection of AGS cells (a gastric adenocarcinoma cell line) was reduced by the presence of CEAE-KP, which also decreased IL-8-induced DMSO-differentiated HL-60 cell (in vitro neutrophil model) chemotaxis by 21.4-57.1\%. Hence, CEAE-KP downregulates both IL-8 expression and its further inflammatory mechanism in neutrophil chemotaxis.

Macrophages play a pivotal role in the innate immune response by eliminating microbes by phagocytosis. However, monocyte chemotaxis occurs before these cells differentiate into macrophages and infiltrate across the endothelial cells to the infected tissue. Chemokines or bacterial antigens act as chemotactic agents and are required to activate monocytes. Monocyte chemotaxis is induced by $H$. pylori proteins through the $\mathrm{N}$-formyl peptide receptor family (FPR) signaling pathway [50, 51]. The induction of THP-1 cell (in vitro monocyte model) chemotaxis by sHP was confirmed in this study, and sHP activated a comparable number of migrated cells as PDGF-BB, a well-known monocyte chemoattractant [52]. Nevertheless, monocyte chemoattraction to sHP was 10-fold lower than that of PDGF-BB, based upon their respective optimal concentration. Some natural products exhibit monocyte attraction, while isothiocyanate decreased stromal cell-derived factor- $1 \alpha$ (SDF- $1 \alpha)$ mediated monocyte chemotaxis and phagocytosis through inhibition of the NF-kB and mitogen-activated protein kinase (MAPK) pathways [53]. CEAE-KP has previously been shown to inhibit monocyte-endothelial adhesion [54], which is the mandatory step before monocyte infiltration into the surrounding tissue. However, this study is the first to report that CEAE-KP downregulated monocyte activity at an earlier step and reduced sHP-mediated monocyte chemotaxis by 30 $60 \%$.

The inhibition of IL-8 production and leukocyte chemotaxis is probably driven by active polymethoxyflavones in the CEAE-KP. HPLC analysis of the ethyl acetate fraction of KP showed 12 main peaks of 7methoxyflavones composed of 4' -hydroxy-5,7-dimethoxyflavone; 5,7,3',4'- tetramethoxyflavone; $3,5,7,3^{\prime}, 4^{\prime}$ - 
pentamethoxyflavone; 5,7-dimethoxyflavone; 5,7,4'-trimethoxyflavone; 3,5,7-trimethoxyflavone; 3,5,7,4' -tetramethoxyflavone; 5-hydroxy-3,7,3',4' -tetramethoxyflavone; 5-hydroxy-7-methoxyflavone; 5-hydroxy-7,4'-dimethoxyflavone; 5-hydroxy-3,7-dimethoxyflavone; and 5-hydroxy3,7,4'-trimethoxyflavone [55]. Dimethoxyflavone and trimethoxyflavone have been indicated as major active compounds that suppress proinflammatory cytokines (induced by IL- $1 \beta$ or TNF- $\alpha$ with IL-17A) via the p38/STAT1 and STAT3 pathways. In addition, a mixture of major active compounds and crude extract of KP more strongly suppressed TNF- $\alpha$ and MMP-13 mRNA expression than individual compounds $[54,56]$. The major component 5,7 , 4 '-trimethoxyflavone also exhibits antiplasmodial, antifungal and antimycobacterial activities [57].

Thus, a comparative study of KP crude extracts and pure active compounds (both individually and as mixtures) should be performed to determine their effect on chemotaxis.

Conclusion CEAE-KP possesses multifunctional antiinflammatory activity against $H$. pylori infection by regulating several major inflammatory mechanisms. CEAEKP inhibited both the initial inflammatory signal (IL-8) from $H$. pylori-infected AGS cells (human gastric cell model) and the relevant leukocyte recruitment. Taken together, KP might be suitable as a part of a novel alternative regimen for ameliorating the inflammation mediated by $H$. pylori infection and decreasing the severity of the disease.

\section{Abbreviations}

KP: Kaempferia parviflora; CEAE: Crude ethyl acetate extract;; sHP: H. pylori soluble protein; IL: Interleukin; DMSO: Dimethyl sulfoxide; PDGF-BB: Plateletderived growth factor-BB

\section{Acknowledgements}

We would like to extend our sincerest gratitude to Graduate School (commemorate the 72th anniversary of his Majesty King Bhumibol Adulyadej scholarship) for providing the Tuition Fee Scholarship as well as to Graduate School and Faculty of Allied Health Sciences at Chulalongkorn University for providing the Overseas Research Experience Scholarship for Graduate Students. Finally, we would like to express our gratitude to Mr. Robert Douglas John Butcher at Research Clinic Unit, Chulalongkorn University for his critical reading of this manuscript.

\section{Authors' contributions}

VN performed the experiment, data analysis and drafted the manuscript; YK designed parts of experiments; TK contributed some reagents and designed parts of experiments; NC conducted the study design, provided reagents and finalized the manuscript. All authors read and approved the manuscript.

\section{Funding}

This work was supported by Faculty of Allied Health Sciences Research Fund (AHS_CU 59009), Chulalongkorn University, 90th Anniversary Chulalongkorn University Fund (Ratchadaphiseksomphot Endowment Fund, GCUG R1125601059M no. 54), and Japan Society for the Promotion of Science KAKENHI (YK, JP17K08976). Funds have been used for experimentation. All funding bodies did not participate in the design of the study, collection, analysis and interpretation of data and in writing the manuscript.

\section{Availability of data and materials}

All data generated or analysed during this study are included in this published article.

\section{Ethics approval and consent to participate}

Not applicable.

\section{Consent for publication}

Not applicable.

\section{Competing interests}

The authors declare that they have no competing interests.

\section{Author details}

${ }^{1}$ Program of Molecular Sciences in Medical Microbiology and Immunology, Department of Transfusion Medicine and Clinical Microbiology, Faculty of Allied Health Sciences, Chulalongkorn University, Pathumwan, Bangkok, Thailand. ${ }^{2}$ Department of Microbiology and Immunology, Tokyo Medical and Dental University Graduate School of Health Care Sciences, Tokyo, Japan. ${ }^{3}$ Research Unit of Innovative Diagnosis of Antimicrobial Resistance, Department of Transfusion Medicine and Clinical Microbiology, Faculty of Allied Health Sciences, Chulalongkorn University, Pathumwan, Bangkok, Thailand.

Received: 27 September 2019 Accepted: 14 April 2020

Published online: 22 April 2020

\section{References}

1. Salehi B, Sharopov F, Martorell M, Rajkovic J, Ademiluyi AO, Sharifi-Rad M, Fokou PVT, Martins N, Iriti M, Sharifi-Rad J. Phytochemicals in Helicobacter pylori infections: What are we doing now? Int J Mol Sci. 2018;19(8):2361.

2. Tongtawee T, Kaewpitoon S, Kaewpitoon N, Dechsukhum C, Leeanansaksiri W, Loyd RA, Matrakool L, Panpimanmas S. Characteristics and risk factors of Helicobacter pylori associated gastritis: a prospective cross-sectional study in Northeast Thailand. Gastroenterol Res Pract. 2016;2016:9130602.

3. Ranjbar R, Khamesipour F, Jonaidi-Jafari N, Rahimi E. Helicobacter pylori in bottled mineral water: genotyping and antimicrobial resistance properties. BMC Microbiol. 2016;16:40.

4. Talaei R, Souod N, Momtaz H, Dabiri H. Milk of livestock as a possible transmission route of Helicobacter pylori infection. Gastroenterol Hepatol Bed Bench. 2015;8:30-6.

5. Fock KM, Ang TL. Epidemiology of Helicobacter pylori infection and gastric cancer in Asia. J Gastroenterol Hepatol. 2010;25(3):479-86.

6. Fock KM. Review article: the epidemiology and prevention of gastric cancer. Aliment Pharmacol Ther. 2014;40(3):250-60.

7. Kuo YT, Liou JM, El-Omar EM, Wu JY, Leow AHR, Goh KL, Das R, Lu H, Lin JT, Tu YK, Yamaoka Y, Wu MS. Primary antibiotic resistance in Helicobacter pylori in the Asia-Pacific region: a systematic review and meta-analysis. Lancet Gastroenterol Hepatol. 2017;2(10):707-15.

8. Talebi Bezmin Abadi A. Vaccine against Helicobacter pylori: inevitable approach. World J Gastroenterol. 2016;22(11):3150-7.

9. Pachathundikandi SK, Tegtmeyer N, Backert S. Signal transduction of Helicobacter pylori during interaction with host cell protein receptors of epithelial and immune cells. Gut Microbes. 2013;4(6):454-74.

10. Shimoyama T, Everett SM, Dixon MF, Axon AT, Crabtree JE. Chemokine mRNA expression in gastric mucosa is associated with Helicobacter pylori cagA positivity and severity of gastritis. J Clin Pathol. 1998;51(10):765-70.

11. Mai U, Perez-Perez G, Wahl LM, Wahl S, Blaser M, Smith P. Soluble surface proteins from Helicobacter pylori activate monocytes/macrophages by lipopolysaccharide-independent mechanism. J Clin Investig. 1991;87(3):894900.

12. Kim JM, Kim JS, Lee JY, Kim YJ, Youn HJ, Kim IY, Chee YJ, Oh YK, Kim N, Jung HC, Song IS. Vacuolating cytotoxin in Helicobacter pylori water-soluble proteins upregulates chemokine expression in human eosinophils via $\mathrm{Ca}^{2+}$ influx, mitochondrial reactive oxygen intermediates, and NF-kappaB activation. Infect Immun. 2007;75(7):3373-81.

13. Allison CC, Kufer TA, Kremmer E, Kaparakis M, Ferrero RL. Helicobacter pylori induces MAPK phosphorylation and AP-1 activation via a NOD1-dependent mechanism. J Immunol. 2009;183(12):8099-109.

14. Takeshima E, Tomimori K, Kawakami H, Ishikawa C, Sawada S, Tomita M, Senba M, Kinjo F, Mimuro H, Sasakawa C, Fujita J, Mori N. NF-kappaB 
activation by Helicobacter pylori requires Akt-mediated phosphorylation of p65. BMC Microbiol. 2009;9:36.

15. Liu T, Zhang L, Joo D, Sun SC. NF-kappaB signaling in inflammation. Signal Transduct Target Ther. 2017;2:e17023.

16. Nozawa H, Chiu C, Hanahan D. Infiltrating neutrophils mediate the initial angiogenic switch in a mouse model of multistage carcinogenesis. Proc Natl Acad Sci U S A. 2006;103(33):12493-8.

17. Torisu H, Ono M, Kiryu H, Furue M, Ohmoto Y, Nakayama J, Nishioka Y, Sone S, Kuwano M. Macrophage infiltration correlates with tumor stage and angiogenesis in human malignant melanoma: possible involvement of TNFalpha and IL-1alpha. Int J Cancer. 2000;85(2):182-8.

18. Wu MH, Lee WJ, Hua KT, Kuo ML, Lin MT. Macrophage infiltration induces gastric cancer invasiveness by activating the beta-catenin pathway. PLoS One. 2015;10(7):e0134122.

19. Okada F. Inflammation-related carcinogenesis: current findings in epidemiological trends, causes and mechanisms. Yonago Acta Medica. 2014:57(2):65-72.

20. Sae-Wong C, Tansakul P, Tewtrakul S. Anti-inflammatory mechanism of Kaempferia parviflora in murine macrophage cells (RAW 264.7) and in experimental animals. J Ethnopharmacol. 2009;124(3):576-80.

21. Kummee S, Tewtrakul S, Subhadhirasakul S. Antimicrobial activity of the ethanol extract and compounds from the rhizomes of Kaempferia parviflora. Songklanakarin J Sci Technol. 2008;30(4):463-6.

22. Chaturapanich G, Chaiyakul S, Verawatnapakul V, Pholpramool C. Effects of Kaempferia parviflora extracts on reproductive parameters and spermatic blood flow in male rats. Reproduction. 2008;136(4):515-22.

23. Ji-Eun P, Hee-Bong P, Wook WS, Jae-Hong J, Jae-Kwan H. The protective effect of Kaempferia parviflora extract on UVB-induced skin photoaging in hairless mice. Photodermatol Photoimmunol Photomed. 2014;30(5):237-45.

24. Qin Y, Cui W, Yang X, Tong B. Kaempferol inhibits the growth and metastasis of cholangiocarcinoma in vitro and in vivo. Acta Biochim Biophys Sin Shanghai. 2016;48(3):238-45.

25. Jeong D, Kim DH, Chon JW, Kim H, Lee SK, Kim HS, Yim JH, Song KY, Kang IB, Kim YJ, Park JH, Jang HS, Kang SH, Kim SK, Seo KH. Antibacterial effect of crude extracts of Kaempferia parviflora (Krachaidam) against Cronobacter spp. and Enterohemorrhagic Escherichia coli (EHEC) in various dairy foods: a preliminary study. J Milk Sci Biotechnol. 2016;34(2):63-8.

26. Chaichanawongsaroj N, Amonyingcharoen S, Pattiyathanee P, Vilaichone R$K$, Poovorawan Y. Anti-Helicobacter pylori and anti-internalization activities of Thai folk remedies used to treat gastric ailments. J Med Plant Res. 2012;6(8): 1389-93.

27. Tewtrakul S, Subhadhirasakul S. Effects of compounds from Kaempferia parviflora on nitric oxide, prostaglandin E2 and tumor necrosis factor-alpha productions in RAW264.7 macrophage cells. J Ethnopharmacol. 2008;120(1):81-4.

28. Rujjanawate C, Kanjanapothi D, Amornlerdpison D, Pojanagaroon S. Antigastric ulcer effect of Kaempferia parviflora. J Ethnopharmacol. 2005;102(1): 120-2.

29. Chaichanawongsaroj N, Amonyingcharoen S, Saifah E, Poovorawan Y. The effects of Kaempferia parviflora on anti-internalization activity of Helicobacter pylori to HEp-2 cells. Afr J Biotechnol. 2010;9(30):4796-801.

30. Banjerdpongchai R, Suwannachot K, Rattanapanone V, Sripanidkulchai B. Ethanolic rhizome extract from Kaempferia parviflora Wall. ex. baker induces apoptosis in HL-60 cells. Asian Pac J Cancer Prev. 2008;9(4):595-600.

31. Kusters JG, Van Vliet AH, Kuipers EJ. Pathogenesis of Helicobacter pylori infection. Clin Microbiol Rev. 2006;19(3):449-90.

32. Rugge M, Meggio A, Pennelli G, Piscioli F, Giacomelli L, De Pretis G, Graham DY. Gastritis staging in clinical practice: the OLGA staging system. Gut. 2007; 56(5):631-6.

33. Thung I, Aramin H, Vavinskaya V, Gupta S, Park JY, Crowe SE, Valasek MA Review article: the global emergence of Helicobacter pylori antibiotic resistance. Aliment Pharmacol Ther. 2016:43(4):514-33.

34. Fallone CA, Chiba N, Van Zanten SV, Fischbach L, Gisbert JP, Hunt RH, Jones $\mathrm{NL}$, Render C, Leontiadis Gl, Moayyedi P, Marshall JK. The Toronto consensus for the treatment of Helicobacter pylori infection in adults. Gastroenterology. 2016;151(1):51-69.

35. Bradley B, Singleton M, Po A. Bismuth toxicity-a reassessment. J Clin Pharm Ther. 1989;14(6):423-41.

36. Liu Y, Zhuang J, Zhang X, Yue C, Zhu N, Yang L, Wang Y, Chen T, Wang Y, Zhang LW. Autophagy associated cytotoxicity and cellular uptake mechanisms of bismuth nanoparticles in human kidney cells. Toxicol Lett. 2017;275:39-48.
37. Haghi A, Azimi H, Rahimi R. A comprehensive review on pharmacotherapeutics of three phytochemicals, Curcumin, Quercetin, and Allicin, in the treatment of gastric cancer. J Gastrointest Cancer. 2017:48(4): 314-20.

38. Bhattamisra SK, Yean Yan VL, Koh Lee C, Hui Kuean C, Candasamy M, Liew YK, Sahu PS. Protective activity of geraniol against acetic acid and Helicobacter pylori - induced gastric ulcers in rats. J Tradit Complement Med. 2018;9(3):206-14

39. Sae-Wong C, Matsuda H, Tewtrakul S, Tansakul P, Nakamura S, Nomura Y, Yoshikawa M. Suppressive effects of methoxyflavonoids isolated from Kaempferia parviflora on inducible nitric oxide synthase (iNOS) expression in RAW 264.7 cells. J Ethnopharmacol. 2011;136(3):488-95.

40. De Monte C, Bizzarri B, Gidaro MC, Carradori S, Mollica A, Luisi G, Granese A, Alcaro S, Costa G, Basilico N, Parapini S, Scaltrito MM, Masia C, Sisto F. Bioactive compounds of Crocus sativus $L$. and their semi-synthetic derivatives as promising anti-Helicobacter pylori, anti-malarial and antileishmanial agents. J Enzyme Inhib Med Chem. 2015;30(6):1027-33.

41. Lu MC, Chiu HF, Lin CP, Shen YC, Venkatakrishnan K, Wang CK. AntiHelicobacter pylori effect of various extracts of Ixeris chinensis on inflammatory markers in human gastric epithelial AGS cells. J Herb Med. 2018:11:60-70.

42. Perera MDN, Robinson JR, Shearn CT, Noble TM, Hallam JE, Kohut ML, Senchina DS. Effects of bloodroot (Sanguinaria canadensis L.) rhizome ethanol extracts on cytokine production by blood mononuclear cells during flowering and fruiting. J Herb Med. 2014;4(1):18-23.

43. Radziejewska I, Borzym-Kluczyk M, Leszczyńska K, Wosek J, Bielawska A. Lotus tetragonolobus and Maackia amurensis lectins influence phospho-IkBa, IL-8, Lewis b and H type 1 glycoforms levels in H. pylori infected CRL-1739 gastric cancer cells. Adv Med Sci. 2018;63(1):205-11.

44. Tangjitman K, Wongsawad C, Kamwong K, Sukkho T, Trisonthi C. Ethnomedicinal plants used for digestive system disorders by the Karen of northern Thailand. J Ethnobiol Ethnomed. 2015;11:27.

45. Eftang LL, Esbensen Y, Tannæs TM, Bukholm IR, Bukholm G. Interleukin-8 is the single most up-regulated gene in whole genome profiling of $\mathrm{H}$. pylori exposed gastric epithelial cells. BMC Microbiol. 2012;12:9.

46. Hollebeecka S, Raasa T, Pirontb N, Schneidera Y-J, Toussaintb O, Larondellea Y, Duringa A. Dimethyl sulfoxide (DMSO) attenuates the inflammatory response in the in vitro intestinal Caco-2 cell model. Toxicol Lett. 2011; 206(3):268-75

47. Hartl D, Krauss-Etschmann S, Koller B, Hordijk PL, Kuijpers TW, Hoffmann F, Hector A, Eber E, Marcos V, Bittmann I, Eickelberg O, Griese M, Roos D. Infiltrated neutrophils acquire novel chemokine receptor expression and chemokine responsiveness in chronic inflammatory lung diseases. J Immunol. 2008;181(11):8053-67.

48. Russo RC, Garcia CC, Teixeira MM, Amaral FA. The CXCL8/IL-8 chemokine family and its receptors in inflammatory diseases. Expert Rev Clin Immunol. 2014;10(5):593-619.

49. De Oliveira S, Rosowski EE, Huttenlocher A. Neutrophil migration in infection and wound repair: going forward in reverse. Nat Rev Immunol. 2016;16(6):378-91.

50. Betten Å, Bylund J, Cristophe T, Boulay F, Romero A, Hellstrand K, Dahlgren C. A proinflammatory peptide from Helicobacter pylori activates monocytes to induce lymphocyte dysfunction and apoptosis. J Clin Invest. 2001;108(8):1221-8.

51. Rossi FW, Prevete N, Montuori N, Ragno P, Selleri C, Marone G, Paulis AD. $\mathrm{Hp}(2-20)$ peptide of Helicobacter pylori and the innate immune receptors: specific role(s) of the formyl peptide receptors. Infez Med. 2012;20(Suppl. 2): $19-25$.

52. Siegbahn A, Hammacher A, Westermark B, Heldin CH. Differential effects of the various isoforms of platelet-derived growth factor on chemotaxis of fibroblasts, monocytes, and granulocytes. J Clin Investig. 1990;85(3):916-20.

53. Reddy SA, Shelar SB, Dang TM, Lee BN, Yang H, Ong SM, Ng HL, Chui WK, Wong SC, Chew EH. Sulforaphane and its methylcarbonyl analogs inhibit the LPS-stimulated inflammatory response in human monocytes through modulating cytokine production, suppressing chemotactic migration and phagocytosis in a NF-kappaB- and MAPK-dependent manner. Int Immunopharmacol. 2015;24(2):440-50.

54. Horigome S, Yoshida I, Ito S, Inohana S, Fushimi K, Nagai T, Yamaguchi A, Fujita K, Satoyama T, Katsuda SI, Suzuki S, Watai M, Hirose N, Mitsue T, Shirakawa H, Komai M. Inhibitory effects of Kaempferia parviflora extract on monocyte adhesion and cellular reactive oxygen species production in human umbilical vein endothelial cells. Eur J Nutr. 2015;56(3):949-64. 
55. Shimada T, Horikawa T, Ikeya Y, Matsuo H, Kinoshita K, Taguchi T, Ichinose K, Takahashi K, Aburada M. Preventive effect of Kaempferia parviflora ethyl acetate extract and its major components polymethoxyflavonoid on metabolic diseases. Fitoterapia. 2011;82(8):1272-8.

56. Kongdang P, Jaitham R, Thonghoi S, Kuensaen C, Pradit W, Ongchai S. Ethanolic extract of Kaempferia parviflora interrupts the mechanismsassociated rheumatoid arthritis in SW982 culture model via p38/STAT1 and STAT3 pathways. Phytomedicine. 2019;59:152755.

57. Yenjai C, Prasanphen K, Daodee S, Wongpanich V, Kittakoop P. Bioactive flavonoids from Kaempferia parviflora. Fitoterapia. 2004;75(1):89-92.

\section{Publisher's Note}

Springer Nature remains neutral with regard to jurisdictional claims in published maps and institutional affiliations.

Ready to submit your research? Choose BMC and benefit from:

- fast, convenient online submission

- thorough peer review by experienced researchers in your field

- rapid publication on acceptance

- support for research data, including large and complex data types

- gold Open Access which fosters wider collaboration and increased citations

- maximum visibility for your research: over $100 \mathrm{M}$ website views per year

At $\mathrm{BMC}$, research is always in progress.

Learn more biomedcentral.com/submissions 